\title{
Celiac disease presented after autologous bone marrow transplantation for acute myelogenous leukemia
}

Sir,

Celiac disease or gluten sensitive enteropathy is defined as a small intestine disorder which leads to mucosal inflammation and villous atrophy after exposure to dietary gluten and causes different features of intestinal malabsorption. ${ }^{[1]}$ Development of celiac disease in cases of acute leukemia after allogeneic bone marrow transplantation (BMT) from Human leukocyte antigen identical siblings who suffered from celiac disease, have been reported in the literature. ${ }^{[2,3]}$ We report the first case of celiac disease presented after autologous BMT for acute myelogenous leukemia (AML).

A 31-year-old man presented with chronic diarrhea. He had a history of AML (M4) since 2.5 years ago. After induction chemotherapy, he had received cycles of consolidation chemotherapy and then underwent autologous BMT since he had not HLA-identical sibling donor. He was under observation in short intervals at Oncology clinic without any abnormal finding except persistent pancytopenia due to a hypocellular bone marrow in a heavily treated patient and without any evidences of AML relapse. In the recent visit, he complained chronic diarrhea and weight loss. Physical examination was unremarkable except for asthenia. Laboratory findings were included in Table 1. Total colonoscopy was normal. Upper gastrointestinal endoscopy showed a loss of folds in the second part of duodenum (D2) and biopsy from D2 showed flattening of duodenal mucosa, intraepithelial lymphocytes, lymphoplasmacytic infiltration in lamina propria, and crypt hyperplasia (Marsh class 3). Immunoglobulin A (IgA) antitissue transglutaminase antibodies (IgA-tTG) was markedly elevated to more than $300 \mathrm{u} / \mathrm{ml}$. Bone mass densitometry revealed osteopenia [Table 2].

Diagnosis of celiac disease was made and gluten free diet, multivitamins and mineral replacement therapy was started. We present the first case of celiac disease that presented 2.5 years after autologous stem cell transplantation for AML.

There are inconsistent reports regarding celiac disease after BMT in patients with acute leukemia. In one report, correction of celiac disease after allogeneic BMT for acute leukemia was reported ${ }^{[4]}$ while another reports show the occurrence of celiac disease in recipients of allogeneic BMT for AML from HLA-matched sibling donors who had suffered from celiac disease. There was no report in the literature regarding celiac disease and autologous BMT. We hereby report the first case of celiac disease presented with chronic diarrhea 2.5 years after autologous BMT for AML. If our presented case had a latent celiac disease that presented 2.5 years after autologous BMT or changes in immune function lead to the occurrence of celiac disease are our unanswered questions. 


\begin{tabular}{|c|c|c|c|}
\hline Test & Value & Unit & Normal ranges \\
\hline WBC & 2300 & $/ \mu l$ & $3500-11,000$ \\
\hline $\mathrm{Hb}$ & 13.5 & $\mathrm{~g} / \mathrm{dl}$ & $13 \cdot 5-16.7$ \\
\hline PLT & 42,000 & $\mid \mu l$ & $150,000-450,000$ \\
\hline AST & 61 & $u / l$ & $<51$ \\
\hline ALT & 78 & $u / l$ & $<51$ \\
\hline Total bil & 0.77 & $\mathrm{mg} / \mathrm{dl}$ & $0.1-1.2$ \\
\hline Direct bil & 0.25 & $\mathrm{mg} / \mathrm{dl}$ & $<0.2$ \\
\hline $\mathrm{Ca}$ & 8.6 & $\mathrm{mg} / \mathrm{dl}$ & $8.5-11.5$ \\
\hline$P$ & 3.8 & $\mathrm{mg} / \mathrm{dl}$ & $2.8-4 \cdot 5$ \\
\hline PT & 13 & S & $11-13$ \\
\hline РTT & 34 & S & $26-39$ \\
\hline $\mathrm{FT}_{4}(\mathrm{ECL})$ & 1.12 & $\mathrm{ng} / \mathrm{dl}$ & $0.7-1.8$ \\
\hline Anti-TTG (IgA) & $>300$ & $\mathrm{u} / \mathrm{ml}$ & $<12$ \\
\hline $\lg A$ & 3.30 & $\mathrm{mg} / \mathrm{dl}$ & \\
\hline HBS Ag & \multicolumn{3}{|c|}{-ve } \\
\hline HCV Ab & \multicolumn{3}{|c|}{-ve } \\
\hline HIV Ab & \multicolumn{3}{|c|}{-ve } \\
\hline Stool exam & \multicolumn{3}{|c|}{ Normal } \\
\hline
\end{tabular}

WBC - White blood cell count; $\mathrm{Hb}$ - Hemoglobin; PLT - Platelet count; AST - Aspartate transaminase; ALT - Alanine transaminase; Ca - Calcium; PT - Prothrombin time; PTT - Partial thromboplastin time; Free T4: Free Thyroxine $\mathrm{ECL}$ - electrochemiluminescence immune assay; $\mathrm{HBS} \mathrm{Ag}$ - Hepatitis B virus antigen; $\mathrm{HCV} A \mathrm{~A}$ - Hepatitis $\mathrm{C}$ virus Antibody; HIV Ab - human immunodeficiency virus antibody; Anti-TTG (IgA) - immunoglobulin A (IgA) anti-tissue transglutaminase antibodies; BMT - Bone marrow transplantation

\begin{tabular}{lcc}
\hline \multicolumn{2}{c}{ Table 2: Results of bone mass densitometry } \\
\hline BMD & T-score & Z-score \\
Spine & -2.4 & -2.4 \\
Hip & -1.7 & -1.4 \\
\hline BMD - Bone mass densitometry & &
\end{tabular}

\section{ACKNOWLEDGMENT}

Special thanks to all Doctors, Nurses and Staffs of Hematology/
Oncology and Stem Cell Research Center in Shariati Hospital of Tehran University of Medical Sciences who performed autologous bone marrow transplant for this patient. We express our appreciation to Drs. Behruz Ilkhanizadeh the pathologist and Samaneh Abedidost resident of the Pathology in Urmia University of Medical Sciences who reported pathologic findings of duodenal biopsy of this case.

\section{Nasim Valizadeh, Kamran Shateri}

Departments of Hematology \& Medical Oncology and ${ }^{1}$ Gastroenterology, Urmia University of Medical Sciences, Urmia, Iran. E-mail: nsedaha0@gmail.com

\section{REFERENCES}

1. Rostom A, Dube C, Cranney A. Celiac disease. Summary, evidence report/technology assessment No 104 (Prepared by the University of Ottawa evidence-based Practice center, under contract, No. 290-02-0021), AHRO publication No 04-E)29-1, Agency for Healthcare Research and Quality, Rockville, MD: 2004.

2. Bargetzi MJ, Schönenberger A, Tichelli A, Fried R, Cathomas $\mathrm{G}$, Signer $\mathrm{E}$, et al. Celiac disease transmitted by allogeneic non-T cell-depleted bone marrow transplantation. Bone Marrow Transplant 1997;20:607-9.

3. Borgaonkar MR, Duggan PR, Adams G. Differing clinical manifestations of celiac disease transmitted by bone marrow transplantation. Dig Dis Sci 2006;51:210-2.

4. Kline RM, Neudorf SM, Baron HI. Correction of celiac disease after allogeneic hematopoietic stem cell transplantation for acute myelogenous leukemia. Pediatrics 2007, 120:e1120-2.

\begin{tabular}{|l|l|}
\hline \multicolumn{2}{|c|}{ Access this article online } \\
\hline Quick Response Code: & \\
& \\
\hline
\end{tabular}

